\title{
Attracting Neighbors: Soft Pow er Competition in East Asia
}

\author{
Yul Sohn*
}

\begin{abstract}
This article explores the dynamics of competition by means of soft power among two key regional states, China and Japan. It demonstrates that, in their embrace of regionalism, each has concentrated soft power on East Asian neighbors by competitively proposing regional visions that would best position it in the regional leadership stakes. China took the initiative, Japan responded quickly, and China is now striking back. This does not necessarily mean that the liberal claim that East Asia is "ripe for cooperation" is misplaced. Nor does it suggest that the realist claim of "ripe for rivalry" better represents the reality. Rather, this article argues that regional powers compete in order to attract neighbors. Since this contest involves embracing others, it is not necessarily a zero-sum game. This article evaluates the success, or lack thereof, of the two countries' efforts in order to learn what they imply for Korea.
\end{abstract}

Keywords: soft power, attraction, regionalism, East Asian community, charm offensive, nationalism

\section{INTRODUCTION}

In the world's greatest military spending area, East Asia seems "ripe for rivalry" (Friedberg, 1993). States are competitively building up military resources with which to coerce others and engaging in "head to head" economic competition. With amassed

\footnotetext{
* Yul Sohn is professor of international studies and chair of the International Studies Program at Yonsei University in Seoul. He has written extensively on Japanese political economy, international political economy, and East Asian regionalism. His most recent works include "Japan's New Regionalism: China Threat, Soft Balancing, and East Asian Community" (Asian Survey, 2010), "A Twenty-First Century East Asia: Contested International Societies" (Journal of World Politics, 2009), "Korea's Japan Policy Under the New ROK Government" (Journal of East Asian Affairs, 2008), and "Whither the Japanese Model?: Evolutionary Changes and the Rise of Many Japans" (Journal of International and Area Studies, 2008).
}

Manuscript received February 10, 2011; out for review February 26, 2011; review completed March 30, 2011; accepted April 8, 2011.

The Korean Journal of Policy Studies, Vol. 26, No. 1 (2011), pp. 77-96.

(C) 2011 by the GSPA, Seoul National University 
economic and energy resources, they want to coerce or induce others to achieve their desired outcomes (Calder, 1997; Kang, 2003; Dittmer, 2004). But at the same time, the incentives for cooperation among states are growing. For the past 50 years or so, East Asia collectively has been an engine for global development; this was the outcome of a chain reaction of national growth, led by Japan, followed by the Four Dragons, ASEAN (Association of Southeast Asian Nations) countries, and China. ${ }^{1}$

East Asia now comes close to the European Union and North America, not only in the size of its economy but also in its level of integration, thanks to a dramatic increase in trade and investment ties within the region. These developments have led national leaders to realize that East Asia is becoming a great whole of which they are part, and that their fate is closely associated with the prosperity of the region. ${ }^{2}$ East Asia seems "ripe for cooperation" (Pempel, 2005).

In a duality that the region presents, rivals compete over how to cooperate. While promoting cooperation in a regional institutional framework, they advocate different alliances, ideas, and role allocations. Each state is architecting a regional institution that would best position it in the regional leadership stakes (Terada, 2006). The upshot is that different regions have been proposed by different states. For example, China has worked to embrace Southeast Asia under ASEAN Plus Three (APT) and Central Asia under the Shanghai Cooperation Organization (SCO). Japan is racing to connect East Asia in the name of an East Asian Community that includes APT plus Australia, New Zealand, and India. The United States has attempted to enlarge the functions of as yet economically oriented APEC (Asia-Pacific Economic Cooperation). Finally, Korea has pursued a Northeast Asian community composed mainly of China, Japan, and Korea. Many of these groupings are incompatible with one another, and they compete for primacy.

In this contest, the key to success is securing the neighbors' consent to membership. For this, sheer military and economic might are not sufficient. We can recall that, despite its overwhelming hard power in the region, prewar Japan failed to build a regional whole (the East Asian Cooperative Unit and the Greater East Asian Co-prosperity Sphere). A crucial need is the ability to draw the voluntary or quasi-voluntary consent of others-that is, soft power. Joseph Nye defines the term as the ability to get others to want a region that it wants (Nye 1990, 1991, 2004a, 2004b, 2004c; Keohane \& Nye, 1998).

1. This is often called the flying geese model. Cumings (1984) uses the product cycle concept to explain this type of regional development.

2. The increasing degree of economic integration is the central feature of East Asian regionalization (see for example Katzenstein and Shiraishi, 1997, 2006; Katzenstein, 1999; Pempel, 2005; Dent, 2008; Yoshimatsu, 2008). 
Now, the conditions for projecting power are dramatically changing as these powers play a soft power game. Accordingly, the resources that provide the best basis for power are changing. Nye demonstrates that key resources include culture, political values, and foreign policies. In East Asia, China and Japan believe that the attractiveness of their country will be crucial to its ability to achieve the outcome of a region that best serves its own ideas and interests. Rather than exclusively putting together military and economic resources, they will benefit if they are able to attract others into their sphere.

This article explores the competitive dynamics of soft power pursuit among key regional states. China pursues its long-term goals of becoming a global power rather than simply a regional one (Kurlantzick, 2007). Japan is working hard to play an active role in global affairs as well. ${ }^{3}$ Nonetheless, both have concentrated soft power on East Asia. The most visible case is Beijing's and Tokyo's competitive embracing of regionalism, which offers a vital window into how they want, build, and use soft power. The present work takes this case and closely examines the ways in which regional orders are proposed and compete for support.

The main contribution of this analysis is twofold. First, it provides an empirical account of regional competition among major states from a soft power perspective. There is a growing body of literature on soft power, which tends to focus on a nationbased analysis of soft power resources and its projection. ${ }^{4}$ Few attempts have been made to address the ways in which states compete by soft power. This work attempts to fill that gap. The increasingly competitive nature of China-Japan relations, it suggests, can be better understood in the context of soft power competition.

Second, this work provides an appraisal of the two countries' soft power and a critical evaluation of its potential. For this, a theoretical understanding of soft power is needed. While many use this concept in academic writing and policy discourse, it is theoretically underspecified. Nye has worked hard to specify soft power resources in order to claim that states with some nonmaterial resources are likely to get what they want in world politics, but he does not specify the mechanisms by which those resources are mobilized and translated into actual power in a specific context. Rather than identifying soft power resources, this article will focus on the ways in which countries use nonmaterial means (sending the "message" of unity) to achieve their

3. This is best illustrated in Japan's posture with regard to the transformation of the US-Japan security alliance (see US-Japan Security Consultative Committee, 2002, 2005, 2006).

4. On China's soft power, see Garrison, 2005; Kurlantzick, 2007; Cho \& Jeong, forthcoming. On Japan, see Shiraishi,1997; McGray, 2002; Kawakatsu, 2006; Ogura, 2004; Leheny, 2006; Otmazgin, 2007. 
ends (leadership in a regional institutional framework).

As Nye points out, soft power depends on the context: what messages are sent and received by whom (Nye, 2004). Messages can be interpreted with different effects by different receivers. When viewed in this context, a receiver's behavioral change can be determined by both the content and the source of the message - and the sender is the wielder of soft power. Whether the content of the message is tailored to the hearts and minds of the receiver is important. A message that arouses strong emotions, for example, is effective. Likewise, the one that presents a firm basis of expertise and elaboration of knowledge is attractive. Equally important is who sends that message. The source of a message may make it easier or more difficult to achieve the desired outcome. When a source is credible, the message is more likely to persuade. Finally, the effectiveness of all this depends on the recipient of the message. Soft power is relational in character. Any appraisal of the two countries' soft power in this analysis will reflect a home-country bias - in this case, a Korean view.

The primary focus of this article is on Chinese and Japanese strategies. I will occasionally address how the United States and Korea are responding to them. I will not, however, directly touch upon the US-East Asian relationship or American soft power. I will first analyze why China has engaged with the region and how it has employed soft power strategies. Then I will observe how Japan has responded to China's initiative, focusing on Japan's goals, strategies, rhetoric, and tools of influence. Having observed these two cases, I will evaluate the success, or lack thereof, of the two countries' efforts, in order to draw policy implications for Korea.

\section{COMPETING BY SOFT POWER}

By the mid-1990s, a new China had emerged on Asia's strategic horizon, shifting gears in foreign policy. Beijing toned down its previous strategy of using military strength to intimidate Asian neighbors by aggressive moves such as sending battleships into the region and calling on others to abandon their alliances, mostly with the United States. Instead, the Chinese leadership focused on a proactive diplomacy in shaping a regional environment conducive to domestic economic development. Beijing tried to maintain peace and stability on its borders and portray itself to others as a benign and constructive actor. ${ }^{5}$ A symbolic move was Beijing's refusal to devaluate its

5. There is an increasing body of literature demonstrating that China's soft power strategies helped to increase its influence in Asia (for example, Acharya, 2003; Lampton, 2005; Shambaugh, 2005; Garrison, 2005; and Kurlantzick, 2007). 
currency during the Asian financial crisis. In sharp contrast to Washington's hawkish neoliberal approach to the crisis, which aroused anger and protest, Beijing worked to strengthen its standing in the region. It advertised its decision as being in the overall interest of maintaining stability and prosperity with a high sense of responsibility. Ever since, Beijing has embraced regional multilateral institutions, pursued free trade agreements with neighbors, and mediated other nations' disputes.

All these moves, aimed at improving its image and influence, were guided by new national strategies based on new concepts (Wang, 2005; Yunling and Shiping, 2005). For example, the widely circulated concept of "comprehensive national power" (zonghe guoli) includes soft power-including political, diplomatic, cultural, and educational power-as an important part. The "new concept of international politico-economic order," "new security concept," and "responsible power" all were devised to increase China's soft power. By the early 2000s, the term heping jueqi, or peaceful rise, developed by Zheng Bijian, a powerful advisor to the Chinese leadership, provided the most important guiding principle of China's foreign policy. By claiming that China will not arise at the expense of others, it purports to allow the Chinese economy to continue growing, undermine the scenario of China as a threat, and portray China as a benign, peaceful, and constructive actor in the world. Peaceful rise is a carefully constructed concept that would allow China to be a global power (Zheng, 2005).

China's soft power strategies aim at a larger national goal: leadership in Asia. While the response to China's soft power extends beyond Asia, including nations from Venezuela to Nigeria, soft power strategies have focused on Asia, shifting influence away from the United States and Japan and creating China's own sphere of influence. After the financial meltdown, East Asian states realized that they had become deeply interdependent on each other, collectively vulnerable to external shocks, and thereby in need of regionwide safety-net institutions that would tame the vagaries of rapidly globalizing markets (Bowles, 2002; Higgott, 1998; Dobson, 2001; Dent, 2003; Munakata, 2005; Weber, 2001).

Given the surge of regionalism among East Asian states, Beijing believed that its future would depend on the stability and prosperity of the region, and decided to take the lead in constructing regional cooperative frameworks. By the early 2000s, Beijing had developed subtle strategies to achieve this goal. One is establishing a leadership position in East Asia through proactive involvement in the APT. The other focuses on Central Asia through an initiative to develop the SCO. Beijing thus began to enunciate a doctrine of "win-win" relations, emphasizing that participants would benefit from their relationships with China. It also proclaimed a doctrine of noninterference, emphasizing that it would listen to the needs and desires of other nations without asking for anything in return (Kurlantzick, 2007). Both were in line with the broader con- 
cept of peaceful rise.

On the economic side, China has pursued soft power strategies in several areas. FTA (Free Trade Agreement) was a strategic tool of engagement. Sensitive to the fear of China's economic rise, the Chinese leadership reassured ASEAN countries by signing FTA and making substantial trade concessions. To the surprise of many ASEAN partners, Beijing offered a trade deal including an "early harvest package" that, even before the FTA comes into effect, would reduce China's tariffs on some Southeast Asian goods. Apparently, this was a conscious strategy for earning goodwill from ASEAN neighbors (Wong and Chan, 2003; Cheng, 2004). It was also a strategy of engagement that uses economic means to ameliorate the non-status-quo elements of a rising power's behavior (Schweller, 1999). Backing up its trade and investment promises, China has also developed a substantial foreign aid program. It now competes with the United States and Japan in Southeast Asia and Central Asia. Again noticeable is the way in which Beijing assists others. Assistance is not explicitly targeted for economic development, but also for cultural and language promotion, and aims to improve friendly cooperation between China and other developing countries (Kurlantzick, 2007, p. 98).

Another major component of China's appeal to Asian nations is Beijing's portrayal of its achievement as a model. Ever since the late 1970s, China's economy has grown rapidly, with real GDP expanding at an average 9 percent. This phenomenal success has led to the wide circulation of what is called the Beijing Consensus. ${ }^{6}$ As conceived in direct contrast to a Washington Consensus involving market-oriented and democratic packages of developmental prescription, the Beijing Consensus provides an alternative path to development better suited to the conditions for developing countries. Like the Washington Consensus, it is not just an economic model, but also a social and political one, because it emphasizes innovation, sustainability, equity, and self-determination. The way in which countries achieve these values is a state-led (top-down) reform that avoids the chaos that can result from rapid growth. And the reform is pursued in an incremental way. ${ }^{7}$ Beijing is clearly advertising this model, with which it seems to have enjoyed success (Kurlantzick, 2007, p. 57).

China's cultural promotion is part of a broader effort at public diplomacy. Beijing has made an effort to increase cultural exchanges with neighbors, expand the international reach of its media, increase networks of informal summits such as a Davos-style world economic forum, and promote Chinese culture and language studies abroad.

6. The term Beijing Consensus was first proposed by Joshua Cooper Ramo, a senior advisor to Goldman Sachs and adjunct professor at Tsinghua University (Ramo, 2004). Since then, it has received international recognition through high-profile media reports.

7. For a critical review of the Beijing Consensus discourse, see Cho and Jeong, forthcoming. 
The establishment of the Confucius Institute (Kongzi xueyuan), a Chinese culturalcum-language center responsible for creating enthusiasm about learning Chinese, is a case in point. In fact, Chinese language and cultural studies have soared in popularity around the world. South Korea is a good example. As China becomes Korea's largest trading partner, a China boom has erupted. Since the establishment of the first Confucius Institute in Seoul in November 2004, 140 institutes had been set up worldwide as of March 2007. Private Chinese language schools have blossomed. The number of Korean students studying in Chinese universities has also rapidly increased. Visits to China by Koreans have skyrocketed and overtaken the number of Japanese visits. ${ }^{8}$

In sum, China's subtle but persistent pursuit of a good neighbor policy, proactive economic engagement, and systematic promotion and dissemination of its own cultural values, all have increased its soft power. By skillfully combining this with rapidly increasing economic and military capabilities, China has successfully increased its influence in Southeast and Central Asia. China's central position in both APT and SCO proves its successful efforts. The response to Chinese soft power now extends to Korea and the rest of the world. By far its greatest impact has been on Japan, however. Japan was pushed into a corner.

Japan has a long history of cultivating influence in Southeast Asia. Ever since the Fukuda doctrine of 1977, the first conscious official effort at embracing this region, Japan has poured in a huge amount of ODA (Official Development Assistance) in the name of economic cooperation (keizai kyōryoku). Until the mid 1990s, Japanese multinational corporations invested heavily in this region in order to establish regional production networks centered on the metropole (Hatch and Yamamura, 1996). Tokyo believed that Southeast Asia was its hinterland. But cash (or hard power) alone did not appeal to the average population in that region.

Japan did not build as much soft power as expected. This did not mean, however, that Japan ignored soft power. By the mid 1990s, several national strategy visions based on the concept of soft power were made public: a group of politicians led by Takemura Masayoshi proposed a "small but shining Japan" vision; and Funabashi Yoichi, a prominent journalist, proposed a "global civilian power" vision. In 1996, Keidanren, a powerful business peak organization, proposed a comprehensive, softpower-driven national strategy in a report called Keidanren Vision 2020: The Creation of an Attractive Japan (miryoku aru nihon no sōzō). This report suggested that Japan create a new identity that gains understanding, trust, and respect from the international society by building a "prosperous and dynamic civil society" and a "nation contribut-

8. As of 2007, the number of cross-visits between Korea and China was 4.8 million, while the number of Korea-Japan visits was 4.2 million. 
ing to global peace and prosperity" (Sohn, 2005).

Japan has been interested in wielding soft power and has well recognized its strategic importance. In attempting to implement soft power strategies, Japan's distinctive cultural traditions are assets. Japanese art, literature, music, design, fashion, and food have long served as global cultural magnets. Japan's popular culture-including J-pop, manga, and animation-is extremely popular among the younger generation in Asia. Shiraishi claims that Japan is playing a key role in creating East Asian middle-class culture (Shiraishi, 2006).

Japan also has great soft power resources in the economic sphere. It was the first non-Western country to achieve modernization and industrialization. Its economic model, the so-called developmental state, has been hailed as an alternative to the Western course of development (Johnson, 1982). There is no doubt that an East Asian brand of capitalism was created by Japan and followed by Korea and other Asian countries. Although the decade-long economic recession tarnished the reputation of the Japanese model, it did not erase the attractiveness of this system. Japanese multinational corporation brands, such as Toyota, Honda, and Sony, illustrate the viability of Japanesestyle capitalism.

Nonetheless, by the late 1990s, the long recession and financial crisis had severely damaged its top-flight economy, and Japan was in disarray (Yukio and Masahiro, 2002). Riddled by self-defeating politics and economic management, Japan's image declined along with its hard power. Tokyo became inward-looking. It focused on its own problems, debated its own economy, feasted on its own scandals, and worried about the society-wide decline in morality. Foreign policy was a secondary concern. If anything, Tokyo was narrowly concerned with strengthening its hard alliance with the United States (Green, 2001). When there was a massive opportunity for Japan to take advantage of reservoirs of overseas investment and aid, Japan walked away from Asia.

It was precisely in this context that China aggressively made inroads in Southeast Asia. When China signed the 2001 Framework Agreement on Economic Cooperation and Establishment of the China-ASEAN FTA, the Japanese were shocked. They did not expect that China would make such a deal. By 2002, China and ASEAN had signed several key agreements, and the next year, China became the first non-ASEAN country to accede to ASEAN's Treaty of Amity and Cooperation. All these efforts left a totally unprepared Japan appalled.

Together with a rapidly growing Chinese economy that helped Japan recover from a long recession, a diplomatically rising China is psychologically jarring to the Japanese who thought their country was the leader in the region (Pyle, 2007). This began to complicate Tokyo's strategic dilemma. Achieving a hard-power balance by strengthening the US-Japan security alliance had limited value, because China's influence was eco- 
nomic and driven by soft power. Japan needed soft-power strategies to counter Chinese influence (Paul, 2004; Pape, 2005).

Japan quickly moved its attention to Southeast Asia. Koizumi visited ASEAN countries during early 2002, and belatedly acceded to ASEAN's Treaty of Amity and Cooperation. Because China signed first, Japan received little attention. Japan came up with a FTA with ASEAN, another belated step. Koizumi belatedly endorsed regional multilateralism, highlighting that Japan would fully utilize APT as its primary regional framework in order to build a community and progress together (Ito, 2005). In order to systematically support this move, a half-private, half-public think tank, the Council on East Asian Community, was established in 2004. Funded by the government, staffed by ex-bureaucrats, headed by former Prime Minister Nakasone Yasuhiro, and participated in by scholars and business people, this organization aimed to counter China's soft power. Ito Kenichi, the founder and leader of the Council, confessed that it was a strategic response to Beijing's initiatives that led the "East Asian think-tank network" (Ito, 2005).

Next, Tokyo came up with a broader East Asian Community (EAC) proposal that has three components. ${ }^{9}$ One is a functional approach. Given the rising nationalism and intra-regional rivalries that make any comprehensive, high-level institutionalization unrealistic, it proposed an approach that focuses on cooperation in the functional areas of trade, investment, finance, environment, and human security, which in turn was expected to create spill-over effects (Ito, 2005; Makoto, 2005).

The second component is the idea of community. This is what makes Japan different from China. In Japanese, the word community is translated as “kyōdotai (共同體), which means a Gemeinschaft-like society. This Japanese usage can be compared with an English usage of community as a broader concept (the international community). Initially, Japan was cautious in using this word. When Koizumi spoke in meetings with ASEAN nations in January 2002, as well as at the Japan-ASEAN summit meeting in December 2003, the word was written in katakana "ko-myu-ni-ti (ユミュニテイ)." By 2004, Japan began to officially use the translation kyōdotai. In Koizumi's speech at the United Nations General Assembly in September, EAC were translated as "higashi ajia kyōdotai (東アジア共同體.” This demonstrates transformation of the meaning: the proposed region is a community that must retain certain norms, values, and ideologies shared by its members (Ito, 2005; Makoto, 2005).

For Japan, the region is more than a collection of states. As such, Japan contended

9. Japan's EAS proposal was presented at a high-level working group of the APT, which met in June 2006. It has been advanced by policy actors such as government officials and think tanks (for example, Yamada, 2005; Ito, ibid.; Makoto, 2005a; and Masahiro, 2005). 
that the East Asia Summit (EAS) should pursue a community based on identity, as in the case of postwar Europe, that emphasizes peace and democracy as its ideals. It suggested that East Asia shape an identity directed toward freedom, democracy, human rights, the rule of law, and market economy — all Western, universal values.

The third component is the enlarged membership. In addition to the existing APT membership (ASEAN 10 plus Korea, Japan, and China), Japan's EAC includes Australia, New Zealand, and India. ${ }^{10}$ They can easily be identified as regional members because they share the above universal values. By 2005, Japan's position had been supported by Singapore and Indonesia for a different reason: both were concerned that ASEAN's influence would decline with the increasing presence of China.

In attracting East Asian people to take part in the EAC, Tokyo defines its role in the EAC as a leader. In a series of public meetings in 2005 and 2006, Aso Taro, one of the most influential political leaders and then minister of foreign affairs, defined Japan in four ways. The first is as a "thought leader" who, through fate, has been forced to face some very difficult issues (such as nationalism, democracy, and environmental destruction) earlier than other Asian neighbors, and through its struggles to resolve these issues, has become something for others to emulate (Aso, 2006, May 3). The second is as a stabilizer who provides security in the region by maintaining and strengthening the US-Japan alliance, and provides prosperity by extending ODA to countries eager to develop (Aso, 2006, May 3). Third, Japan is a country that respects others as peers and equals; and fourth, Japan plays a key role in creating a knowledge network in East Asia (Aso, 2006, May 26).

Just as Beijing has attempted to establish its sphere of influence beyond the scope of East Asia (for example, by cultivating SCO in Central Asia), so has Tokyo. Tokyo added a new pillar for diplomacy by creating an Arc of Freedom and Prosperity that helps countries on the edges of the Eurasian continent-from Northern Europe to Central Asia, Southeast Asia, and Northeast Asia—to support economic prosperity and democracy by cooperating in the areas of trade, investment, and official development assistance (Aso, 2006, November 30). It can be interpreted as countering SCO and potentially encircling China.

By 2005, Japan's counter-strategies seemed to work. A case in point is the EAS. Beginning in 2004, China and Japan have competed for the initiative in shaping the structure and modality of the EAS, proposed earlier at APT. They have also hotly contested the site for the summit. When Beijing opposed the enlargement of membership to include Australia, New Zealand, and India, its ambition for leadership became

10. To Japan, a deepening of interdependence with these three countries is clear; see Kazuko, 2006. 
apparent. Opposition from Singapore and Indonesia emerged. Japan's attractive proposal for an open regionalism was successful in mustering their support (Terada, 2005, 2006).

\section{EVALUATING SOFT POWER}

China's soft power diplomacy is impressive indeed. As Shambaugh says, "bilaterally and multilaterally, Beijing's diplomacy has been remarkably adept and nuanced, earning praise around the region. As a result, most nations in the region now see China as a good neighbor, a constructive partner, a careful listener, and a nonthreatening regional power (Shambaugh, 2004-2005). Kurlantzick (2007) calls China's approach a "charm offensive." As discussed earlier, China's skillful diplomacy has been guided by principles such as noninterference, respect for other nations' internal affairs, socioeconomic gradualism, and peaceful rise, all of which could be appealing to its neighbors.

Do these messages arouse strong emotions, such as Asian solidarity, that could influence the behavior of China's neighbors? Are they based on firm, sophisticated knowledge and expertise that make them persuasive? The principles advocated by Beijing are of general use; they are not tailored to address what is specifically needed for Asians. Beijing has yet to prepare an elaborate ideational or institutional framework under which Asians can get together. In the case of the EAS, Beijing tried to counter Japan's concept paper that elaborated the content and method of the EAC, but came up short with a so-called modality paper that did little but reject Japan's proposal to co-chair the summit (Terada, 2006). Beijing wanted the EAS to be a virtual replica of the APT in which it could establish de facto leadership. At this point, Kurlantzick's observation deserves attention: China's charming image might recede as the honeymoon period ends; the world will focus more intensely and critically on what Beijing says as it becomes powerful (Kurlantzick, 2007).

Japan has provided by far the most sophisticated content of any of the competing regionalist messages. Its EAC proposal of open regionalism is realistic and persuasive, given the presence of the United States as well as Australia and India as important stakeholders in the region (Katzenstein, 2006; Lincoln, 2003). Likewise, Japan's functionalist approach is realistic, given the diverse, unequal, and often conflictual nature of the East Asian region, which renders almost impossible the creation of an institutional whole such as the European Union. Finally, an EAC based on the concept of community is attractive because of community's importance in the Asian traditionspecifically, the Chinese/Confucian civilization that idealized a Gemeinschaft-like 
world of obligation and harmony. In other words, the content of Japan's message is persuasive, based on a realistic judgment of regional conditions as well as the use of knowledge potentially attractive to the people in the region.

Japan's dilemma, however, is that the attraction of the message is likely to decrease when the source of the message is Japan. For Asians, Japan's promotion of the community concept is reminiscent of its earlier attempts to establish an East Asian Cooperative Unit and Greater East Asian Co-prosperity Sphere, the identity of which was embedded in traditional Asian values (Najita \& Harroutunian, 1988). Given its failure to come to terms with its past vis-a-vis Asia, Japan is not a credible source for this message.

In order to avoid Asians' doubt (or fear), Tokyo has attempted to claim that a community's identity should be based on universal values such as democracy, freedom, human rights, rule of law, and market economy. This is in line with what is called value diplomacy. ${ }^{11}$ Tokyo calls for value promotion as a key pillar of its diplomacy. When viewed in the Asian context, however, this message is not so appealing. It sounds too American, and suggests that Japan is too close an American ally. ${ }^{12}$ Nonetheless, Aso Taro and MOFA (Ministry of Foreign Affairs) officials took great pains to justify those "Western-flavor" concepts, arguing that they have been ingrained in Japan's tradition since the Edo period (Aso, 2006, November 30).

Here, Leheny's observation deserves mention: Japan's increasing attention to soft power has less to do with an evaluating tool for its regional importance than a device for grasping and even justifying what Japan now sees as its regional role (Leheny, 2006). The prospects for this approach are not encouraging. Audiences in East Asia do not see Japan in that way. Japanese efforts remind them of Japan's enduring image of ambiguity and ambivalence: a Japan vacillating between "leave Asia (datsu-A)" and "reenter Asia (nyu-A)" (Kensaburo, 1995). This image leads to the following question: Does Japan have a genuine interest in Asian regionalism? Is it a catalyst or a spoiler? (Chan, 2006).

In contrast to a Japan that sends a well-articulated, seemingly attractive message while falling short of establishing itself as an attractive and reliable source, China has been relatively successful in establishing an attractive image, while not yet prepared to send an elaborated message that caters to the hearts and minds of its neighbors. After a

11. See Ministry of Foreign Affairs at http://www.mofa.go.jp/mofaj/gaiko/free_pros/pdfs/ shiryo_01.pdf.

12. For example, Koizumi was dubbed an Asian Blair for his whole-hearted support of the United States (People's Daily, 2004). His US-centered diplomatic posture has been widely criticized among Korean opinion leaders (Rozman, 2007). 
temporary setback in the race for EAS in 2004-2005, Beijing is preparing a new discourse to strike back. A case in point is its recent claim that it offers a "new Asianism," based on a new definition of Asian values, in contrast to Japan-led "old Asianism." Using Chinese civilization, particularly some attributes of Confucianism, it heralds a new civilization, or what Zheng Bijian calls a renaissance of Chinese civilization under the concept of "harmonious world" (Cho and Jeong, forthcoming).

By 2001 Beijing had worked to combine Confucian virtues and socialist collectivism. These efforts have been further strengthened by the Hu Jintao leadership, which developed the Confucian version of democracy (minben zhuyi), composed of "considering people as fundamental," being "close to the people," "harmonious society," and a "socialist view of honor and disgrace." By extension, just as a new China is progressing by peaceful means based on revitalized Chinese culture and civilization, so will a new Asia be a harmonious world helped and guided by that civilization. By elevating its own culture and practice to the level of civilization, Beijing is searching for a universal element in its claim. While a concrete vision is yet to be seen, given that the past plays a significant role in forming present identity, Chinese civilization can be seen as a potentially great cultural magnet in the region.

By far the greatest challenge both China and Japan have faced and will face lies in the question of nationalism. The credibility of a source is undermined when the source promotes an international position that clearly furthers its interests. Given the resurgence of nationalism in both societies, which leads to their striving for leadership in Asia, any attempt to assume the leading role in the creation of a regional community is hardly trustworthy. China's setback in the EAS proves this. Despite repeated commitment to multilateralism, when Beijing's aspiration for the leadership role in an exclusive regional setting became apparent, Asians turned back. They warned that Beijing seems to be using this multilateral institution as a cover, aiming to deter Japanese and American influence in East Asia (Terada, 2006). Likewise, when Japan's drive for regionalism was seen as a clear balancing act against China's rise, its attractiveness declined.

When nationalism disguised by regionalism, domestically, leads to an increasing tendency to glorify the past, a nationalist source image is combined with, and overshadowed by, imperialism. Because the recipients' experience prior to receiving the message is important, any attempt to assume the leading role without attenuating the nationalist impulse would inevitably cause apprehension about the potential revival of a history of imperial domination.

Inherent in both Chinese and Japanese politics is the dilemma that messages to their populace for reasons of domestic popularity, legitimacy, and even regime survival undermine their external soft power. The best example is the history dispute. Just as Japan has never fully repudiated its past aggression, so has China not fully come to 
terms with its imperial past. Both countries have been engaged in history disputes with their neighbors. For example, Korea's recent dispute with China over the history of the Koguryo Kingdom has generated a sharp decline of China's popularity among Koreans. The territorial disputes over the Tokdo islands, compounded by the Japanese prime minister's official visit to the Yasukuni Shrine, created massive popular resentment, putting Japan's popularity at its worst in postwar history. The suspicion that lingers in countries such as Korea limits China's and Japan's soft power.

Meanwhile, Japan's deficit in credibility is exacerbated by charges of a double standard. For example, Japan's recent claim of value diplomacy, such as promoting human rights, is inconsistent with its partial denial of the comfort woman issue, a critical human rights issue (Dudden, 2006). The latter is in contrast with its adamant position vis-à-vis North Korea on the abduction issue, which it frames as a human rights case. China's liability lies in its undemocratic political system, in which the Communist Party is hesitant to allow too much intellectual freedom and outside influences. According to Keohane and Nye (1998), in the information age, there is clearly a democratic advantage in gaining reputation and soft power, because credibility comes from the democratic - transparent and accountable-procedures by which information is validated, edited, filtered, and interpreted. That China's reporting on defense every two years falls far short of the global standard of transparency is a good example of ways that China loses credibility.

\section{CONCLUSION: IMPLICATIONS FOR KOREA}

In the midst of the soft power contest between China and Japan, what should Korea do? What can Korea learn from their practices? Korea faces an apparent deficit in hard power, situated at the crossroads of great powers. A wise strategy for Korea would be to fill this void by fortifying its soft power. This differs from a great power's strategy in which soft power complements military and economic might. Korea should make greater investments in its soft power than do great powers.

Because Korean foreign policy is struggling to solve the peninsula question, almost all its diplomatic tools and foreign assistance have been directed toward North Korea and the four great powers. Diplomacy and foreign assistance efforts outside the peninsula are largely understaffed, underfunded, and underused. They are neglected in part because of the difficulty of demonstrating their short-term effect on progress toward a peaceful peninsula.

Korean foreign policy has tended to view soft power as a cultural phenomenon. In this view, soft power strategy lies in the field of cultural diplomacy. Soft power is 
more than mere cultural power, however. Although the appeal of popular culture can play a role in inspiring the desires of others, cultivating political ideas and values and performing skillful diplomacy are of far greater importance. Washington, Beijing, and Tokyo clearly understand this point. They pursue soft power as a national strategy that encompasses diverse tasks. In Seoul, on the other hand, there are limits to the understanding of decision makers as to what soft power means and what it can achieve on its own.

Korea is working toward a vision and policy capable of overcoming these obstacles. Despite its status as a latecomer in the region, it has potential. Both China and Japan have recently created problems that undercut their own soft power. China has demonstrated an increasingly offensive posture in the case of several territorial disputes (such as the Senkaku islands and South China Sea) that contradicts its previously cautious charm offensive. Its suppression of human rights also undercuts its soft power. In a different way, Japan is appearing to drift in its recent efforts to "Asia shift" as well as its pursuit of an equal relationship with the United States, which led to the fall of the Hatoyama cabinet. Japanese leadership has also changed too frequently, causing indecision and delay. On the international scene, the Japanese voice has nearly disappeared.

Korea can take advantage of the mistakes of these two countries to develop a strategy based on four principles. First, Korea's soft power strategy must be appropriate to its position as a middle power in the global system. Judged from a hard power perspective, Korea will not be able determine the regional order. But neither is it so weak as to have to decide between Beijing and Tokyo/Washington. By improving its soft power, Korea can play a constructive role as an arbiter or broker who helps to avoid a zero-sum game, or possibly a collision course, among the great powers in the region.

Second, Korea's success in the arbiter's role will turn on its ability to win credibility from others. Both China and Japan fall short in their credibility and ability to inspire hope and optimism. At the core of the problem is that they are self-centered and nationalistic. In this sense, the key to gaining credibility is overcoming self-centered nationalism and establishing consistency in words and action.

Third, overcoming a myopic, inward-looking, short-term mindset is extremely important. Effort spent on the Korean peninsula (for example, regarding North Korea or the Six Party Talks) will not necessarily bring comparable improvement in security and peace. Korea's bargaining power with neighboring states can be increased by its efforts outside the peninsula. This may not produce the desired outcomes immediately; such efforts often work indirectly and may take years to bear fruit. Given Korea's limited budget and the need for trade-offs among policies, it is difficult to invest in the regional and global good, but it would be wise. Korean foreign policy should broaden its perspective to include a regional and global dimension. 
Finally, those who improve networking power will gain a competitive edge in today's world. The soft power strategies of both China and Japan are very much governmentdriven. Governments always take the initiative in creating and disseminating soft power. However, many critical soft power resources are private. The key to success is to think of a soft power increase in terms of connections of activities, linked through flows of potential resources into networks. Here, the role of the government is providing an infrastructure and environment that allow creative experimentation by private individuals and groups, and establishing networks that constitute relational structures and processes in which creative actors interact.

\section{REFERENCES}

Acharya, A. 2003, November 8. China's charm offensive in Southeast Asia. International Herald Tribune.

Aso, T. 2006, May 3. Asian strategy as I see it: Japan as the "thought leader" of Asia. Speech by Minister for Foreign Affairs Taro Aso at the Foreign Correspondents' Club of Japan. http://www.mofa.go.jp/mofaj/press/enzetsu/18/easo_0503.html. . 2006, May 26. A networked Asia: Conceptualizing a future. Speech by Minister for Foreign Affairs Taro Aso on the occasion of the 12th Nikkei International Conference on the Future of Asia. http://www.mofa.go.jp/announce/ fm/aso/speech0605-2.html.

. 2006, November 30. Arc of freedom and prosperity: Japan's expanding diplomatic horizons. Speech by Minister for Foreign Affairs Taro Aso on the occasion of the Japan Institute of International Affairs Seminar. http://www. mofa.go.jp/announce/fm/aso/speech0611.html).

Bowles, P. 2002. Asia's post-crisis regionalism. Review of International Political Economy 9(2).

Calder, K. 1997. Asia's deadly triangle: How arms, energy and growth threaten to destabilize Asia-Pacific. London: Nicholas Brealey.

Chan, B. 2006, January 3. East Asia summit: The result analysis. Mirae Nondan.

Cheng, J. Y. 2004. The ASEAN-China free trade area: Genesis and implications. Australian Journal of International Affairs 2: 257-277.

Cho, Y., \& Jeong, J. forthcoming. China's soft power: Discussions, resources, prospects. Asian Survey.

Cumings, B. 1984. The origin and development of the Northeast Asian political economy. International Organization 38(1):1-40.

Dent, C. 2003. Networking the region: The emergence and impact of Asia-Pacific 
bilateral trade agreement projects. The Pacific Review 16(1). . 2008. East Asian regionalism. London: Routledge.

Dittmer, L. 2004. The emerging Northeast Asian regional order. In S. Kim (ed.), The international relations of Northeast Asia. Oxford: Rowman and Littlefield.

Dobson, W. 2001. Deeper integration in East Asia. World Economy 24(8).

Dudden, A. 2006, April 22. US congressional resolution calls on Japan to accept wartime crime to comfort women. Japan Focus.

Friedberg, A. 1993. Ripe for rivalry: Prospects for peace in a multipolar Asia. International Security 18(3).

Garrison, J. A. 2005. China's prudent cultivation of "soft" power and implications for U.S. policy in East Asia. Asian Affairs: An American Review 32(1): 25-30.

Green, M. 2001. Japan's reluctant realism. New York: Palgrave.

Hatch, W., \& Yamamura, K. 1996. Asia in Japan's embrace. Cambridge: Cambridge University Press.

Higgott, R. 1998. The Asian economic crisis: A study in the politics of resentment. New Political Economy 3(3).

Johnson, C. 1982. MITI and the Japanese miracle: The growth of industrial policy, 1925-1975. Stanford, CA: Stanford University Press.

Kang, D. 2003. Getting Asia wrong. International Organization 27.

Katzenstein, P. J. (ed.). 1999. Asian regionalism. Ithaca, NY: Cornell University Press. 2006. A world of regions. Ithaca, NY: Cornell University Press.

Katzenstein, P. J., \& Shiraishi, T. (eds.). 1997. Network power: Japan and Asia. Ithaca, NY: Cornell University Press. 2006. Beyond Japan: The dynamics of East Asian regionalism. Ithaca, NY: Cornell University Press.

Kawakatsu, H. 2006. Bunkaryoku: Nihon no sokojikara. In Cultural power: Japan's latent power. Tokyo: Wedge.

Kazuko, M. 2006. Higashi ajia kyodotai no kochiku (4): tosetsu netowaku kaiseki. Iwanami.

Kenichi, I. 2005a. Higashi ajia kyodotai to nihon no shinro [East Asian community and Japan's direction]. NHK: 55-56. . 2005b. Higashi-ajia to nihon no shinro. NHK shuppan: 2.

Kensaburo, O. 1995. Aimai na nihon to watashi. Kodansha.

Keohane, R., \& Nye, J. 1998. Power and Interdependence in the Age of Information. Foreign Affairs 77(5).

Kurlantzick, J. 2007. Charm offensive: How China's soft power is transforming the world. New Haven, CT: Yale University Press.

Lampton, D. M. 2005. China's rise in Asia need not be at America's expense. In D. 
Shambaugh (ed.), Power shift: China and Asia's new dynamics (pp. 317-319). Berkeley: University of California Press.

Leheny, D. 2006. A narrow place to cross swords: Soft power and the politics of Japanese popular culture in East Asia. In P. J. Katzenstein \& S. Shiraishi (eds.), Network power: Japan and Asia. Ithaca, NY: Cornell University Press.

Lincoln, E. 2003. East Asian economic regionalism. Washington, DC: The Brookings Institution.

Ito, K. 2005 (ed). Higashi-ajia kyodotai to nihon no shinro. Tokyo: Nihon keizai shimbunsha.

Masahiro, K. 2005. Higashi-ajia kyodotai. Nihon keizai shimbunsha 2005.

McGray, D. 2002. Japan's Gross National Cool. Foreign Policy 130: 44-54.

Munakata, N. 2005. Has politics caught up with markets?: In search of East Asian economic regionalism. In P. J. Katzenstein \& T. Shiraishi (eds.), Beyond Japan. Ithaca, NY: Cornell University Press.

Najita, T., \& Harroutunian, H. 1988. Japan's revolt against the West. Cambridge History of Japan, Vol. 6. Cambridge: Cambridge University Press.

Nye, J. 1990. Soft power. Foreign Policy 80.

. 1991. Bound to lead: The changing nature of American power. New York: Basic Books.

. 2004a. Soft power and American foreign policy. Political Science Quarterly $119(2)$.

2004b. Soft power: The means to success in world politics. New York:

Public Affairs. . 2004c. The decline of American soft power. Foreign Affairs.

Nye, J., \& Keohane, R. 1998. Power and interdependence in the age of information. Foreign Affairs.

Ogura, K. 2004. Kokusai zai no shin ni kachi koso sekai ni hasshin shiyo [Sharing Japan's cultural products as "international assents"]. Chuo Koron.

Otmazgin, N. K., 2007. Contesting soft power: Japanese popular culture in East and South East Asia. International Relations of the Asia-Pacific.

Pape, R. 2005. Soft balancing against the United States. International Security 30(1): 7-45.

Paul, T. V. 2004. Introduction: The enduring axioms of the balance of power theory and their contemporary relevance. In T. V. Paul, J. Wirtz, \& M. Fortmann (eds.), Balance of power: theory and practice in the twenty-first century (pp. 1-24). Stanford: Stanford University Press.

Pempel, T. J. (ed.). 2005. Remapping East Asia: The construction of a region. Ithaca, NY: Cornell University Press. 
Pyle, K. 2007. Japan rising: The resurgence of Japanese power and purpose. Public Affairs.

Ramo, J. C. 2004. Beijing consensus. London: The Foreign Policy Centre.

Rozman, G. 2007. South Korea and Sino-Japanese rivalry: A middle power's options within the East Asian core triangle. The Pacific Review 20(2): 209.

Schweller, R. 1999. Managing the rise of great powers. In A. I. Johnston \& R. Ross (eds.), Engaging China: The management of an emerging power (p. 14). London: Routledge.

Shambaugh, D. 2004-2005. China engages Asia: Reshaping the regional order. International Security 64.

2005. Return to the Middle Kingdom? China and Asia in the early twentyfirst century. In Power shift: Robert G. Sutter, China's rise in Asia: Promises and perils. Lanham, MD: Rowman \& Littlefield.

Shiraishi, S. 1997. Japan's soft power: Doraemon goes overseas. In P. J. Katzenstein, \& S. Shiraishi (eds.), Network power: Japan and Asia. Ithaca, NY: Cornell University Press.

2006. The third wave. In Beyond Japan: The dynamics of East Asian regionalism (pp. 237-272). Ithaca, NY: Cornell University Press.

Sohn, Y. 2005. Ilbon eui [Japan's soft power]. In Y. Ha \& S. Kim (eds.), Mae-ryeok kukka mandeulki [Making of an attractive nation]. Seoul: Dong-A Ilbo.

Taniguchi, M. 2005. Higashi-ajia kyodotai. Tokyo: Iwanami shoten.

Terada, T. 2005. Japan-Australia partnership in the era of East Asian community: Can they advance together? Pacific Economic Papers 352: 15-16.

2006. Forming an East Asian community: A site for Japan-China power struggles. Japanese Studies 26(1): 1-13.

US, Japan establish military alliance. 2004, June 25. People's Daily.

US-Japan Security Consultative Committee. 2002, December. Joint statement of the US-Japan Security Consultative Committee. . 2005, February. Joint statement of the US-Japan Security Consultative Committee.

. 2006, March. Joint statement of the US-Japan Security Consultative Committee.

Wang, J. 2005. China's multilateral diplomacy in the new millennium. In Y. Deng \& F. L. Wang (eds.), China rising: Power and motivation in Chinese foreign policy (pp. 159-200). Lanham, MD: Rowman \& Littlefield.

Weber, D. 2001. Two funerals and a wedding? The Pacific Review 14(3).

Wong J., \& Chan, S. 2003. China-ASEAN free trade agreement: Shaping future economic relations. Asian Survey 3: 507-526. 
Yamada, T. 2005. Toward a principled integration of East Asia: Concept of an East Asian community. Gaiko Forum.

Yoshimatsu, H. 2008. The political economy of regionalism in East Asia. London: Palgrave.

Yukio, M., \& Masahiro, O. 2002. Heisei Baburu no kenkyu. Toyo keizai shinposha 2.

Yunling, Z., \& Shiping, T. 2005. China's regional strategy. In D. Shambaugh (ed.), Power shift: China and Asia's new dynamics (pp. 48-68). Berkeley: University of California Press.

Zheng, B. 2005. China's peaceful rise to the great Power status. Foreign Affairs. 